\title{
The role of ideology in evaluations of (in)appropriate behaviour in student-teacher relationships in China
}

\author{
Daniel Kádár \\ University of Huddersfield
}

In this paper I examine Chinese perceptions of (in)appropriateness and offence from a cross-cultural pragmatic point of view, by exploring (in)appropriate evaluations in the context of a major social offence, and the influence of Confucian ideology on people's evaluative tendencies. By doing so, I aim to contribute to pragmatic understandings of Confucianism as an ideology that underpins evaluative attitudes in Chinese culture. On the theoretical level, I argue that one needs to carefully examine dimensions of ideologies that underlie evaluative tendencies, and also the ways in which ideologies are invoked, rather than making sweeping claims. I believe that is possible to adopt 'ideology' as an analytic notion in interpersonal pragmatics and (im)politeness research, but only if the influence of ideology on interpersonal interaction and evaluative tendencies is captured with the aid of qualitative and quantitative evidence, that is, only as far as one avoids using a certain ideology as an umbrella term to analyse culturally-situated data.

Keywords: ideology, (in)appropriateness, offence, evaluation, Confucianism

\section{Introduction}

The aim of this paper is to draw attention to some challenges of studying Chinese (in)appropriate behaviour and offence from a cross-cultural pragmatic angle, by exploring the relationship between evaluations and Confucianism. I argue that in order to understand the ideological underpinnings of "(in)appropriateness" in Chinese, one needs to carefully examine dimensions of ideologies that underlie evaluations, and also the ways in which ideologies are invoked, rather than making sweeping claims. That is, as far as one intends to identify cross-culturally distinctive features of Chinese (in)appropriateness, it is not enough to focus only 
on seemingly culture-specific interactional phenomena and connect such phenomena with the umbrella term 'Confucianism'. By undertaking this research I aim to contribute to broader examinations of discourse and ideology (e.g. Van Dijk 2011), cross-cultural/intercultural pragmatics (see an overview in Kecskes 2013), and language in society in general, by approaching this issue from my area of (im)politeness research, which provides some alternative insights into ideologies, due to its approach to interaction vis-à-vis evaluative moments and practices (Eelen 2001).

\subsection{Confucianism as an 'umbrella' term}

The present query is centred on the notion of 'Confucianism' in Chinese school conflicts, and so it is worth clarifying what this term covers in my interpretation. 'Confucianism' is often used in the field to describe an ideology, which prescribes a group of ethical values that influence modern politeness behaviour. Just to mention two examples, Low (2010) attempts to connect norms of customer service with Confucian principles, and Li and Moreira (2009) describe the norms of doing business in Chinese within a predominantly Confucian framework. I believe that there are some problems with applying 'Confucianism' without specifying exactly what this notion covers, for various reasons:

- Confucianism as a philosophy was created by Confucius (551-479 BC), Mencius (372-289 BC), Master Xun (310-235 BC) and some other ancient scholars. After the foundation of the Han Dynasty it (220 BC-200 AD) had become a state ideology, which had been in continuous competition with other ideologies, including the ancient Taoism, and the then-new ideology of Buddhism that reached China from India during the first millennium. As Chan (1963) explains, this competition ended with a reconciliation process by the time of the Song Dynasty (960-1127), in the course of which Chinese thinkers created what is often referred to as 'Neo-Confucianism' or Lixue 理学. Neo-Confucianism is a philosophical synthesis of Confucianism, Taoism and Buddhism, which has become a most influential Chinese ideology. This historical development implies that when it comes to discussions on 'Confucianism', we have to be clear that we are essentially talking about Neo-Confucianism and not Confucianism in its original sense.

- As sinologists such as Zhang (2007) make clear, until the 20th century Confucian etiquette included a system of (semi-)religious rituals to be performed on a daily basis. These ritual practices have very little relationship with the practices which are described via the notion of 'Confucianism' in the pragmatics/business language/intercultural communication literature. 
- Many of the so-called 'Confucian' principles, such as 'a strict lecturer produces good disciples', are actually folk interpretations of Confucian thinking - often they do not appear at all in the Confucian philosophical literature - and as such they are Neo-Confucian in nature. ${ }^{1}$

In sum, I use 'Confucianism' in a specific way, as a popular ideology that underlies people's daily evaluations, and which is not necessarily a philosophy in a conventional sense. As a matter of course, this popular ideology often manifests itself in the form of moralising and philosophical discourses and metadiscourses (Cameron 2004) when it comes to my data of clashes between teachers and students in Chinese schools.

There is a tendency of using 'Confucianism' as a magic word in cross-cultural and intercultural pragmatics (see e.g. Hong 1985; Yum 1988; Gu 1990; Huang 2008; Zhu 2009): scholars tend to interpret certain Chinese interactional phenomena as culture-specific, and identify Chinese ideology as a reason for this culture-specificity. For example, in a recent article, Zhu (2009) claims that Chinese letters of invitation are different from Western ones, as they are imbued with Confucian ethics, which embraces both qing (emotion) and $l i$ (reason) and relevant ethical values such as guanxi (connections). This argument raises certain questions. First, is there such a thing as a uniform 'Western' politeness practice for invitation letters? That is to say, is it possible to evidence that Brits, Hungarians, Italians and the Swedish, for instance, use the same formulae and rhetoric in this genre? Can such a cultural description of Chinese invitation letters be upheld if we undertake a major multilingual corpus-based inquiry? This is a key problem, as it is often the case that interactional phenomena, such as self-denigration and other-elevation, which seems to be distinctively Chinese or 'Eastern' (Gu 1990), have their counterparts in the West (see Pan and Kádár 2012). Second, and more importantly, it is problematic to fetishise ideological metaterms such as guanxi or qing, as it is often the case that the moral principles embodied by these metaterms exist in other cultures under different names (see Kádár et al., forthcoming). Third, moral values do not necessarily translate directly into language use.

1. An important characteristic of folk wisdom is that it evolves with historical developments. For example, during the so-called 'Cultural Revolution' (1966-1974) in China, the ideal of respecting teachers was expelled as a normative ideology, but it was revived after Deng Xiaoping's reform (1978). Since that time, this Neo-Confucian folk wisdom has become very important as an ideology (Bell 2010), and a variety of treatises have been published on the respect of teachers - as a noteworthy example, it is pertinent here to refer to children's books such as Yingxiang qingshaonian de 100 ge zunshi jingye gushi 影响青少年的100个尊师敬业故事 (Hundred Stories to Teach the Respect of Teachers and Work to the Youth), a popular work by Liaohai (辽海) Publishing that appeared in 2009. 
Indeed, there is a clear connection between Chinese normative behaviour and Confucian ideology: e.g. the semantic features of certain Chinese honorifics reflect Confucian ideological values (Pan and Kádár 2012), and certain normative ritual practices are codified by Confucian etiquette manuals (Kádár 2007; 2013); the same applies to certain popular metadiscourses on appropriate behaviour, such as Chinese business etiquette manuals which tend to be Confucian by nature (e.g. Fang 1999; Bucknall 2002). However, it can be argued that forms of address, rituals of invitations and other formal manifestations of Chinese normative behaviour only represent a narrow, albeit important, aspect of what the pragmatics of Chinese interpersonal behaviour encompasses. Also, it is highly debatable whether such formal and/or recurrent forms of behaviour play an important role in colloquial day-to-day interactions (see Pan's 2000 seminal study). While it can be argued that Confucian ideology pervades official Chinese perceptions of 'appropriate' language and language use (see Wang et al. 2015), it is difficult to find evidence as to whether it influences ordinary Chinese interactional perceptions and observer understandings of (in)appropriateness. This is because Confucianism in both its traditional and modern forms is essentially a state ideology, as Fukuyama's (1995) seminal study has demonstrated, and so if one intends to find evidence for its ordinary interactional operation, evidence should be sought beyond language policy.

In addition to these points, there are two issues rooted in politeness theory, which make the use of 'Confucianism' as a cross-cultural pragmatic concept even more problematic:

a. Politeness comes into existence in evaluative practices (e.g. Eelen 2001). Therefore, any attempt to categorise forms of Chinese behaviour that trigger evaluations of (im)politeness as 'Confucian' by only looking into forms, or even Brown and Levinsonian (1987) 'strategies', ignores the fundamental interactional nature of (im)politeness. In this respect there seems to be a gap between recent linguistic (im)politeness research and a large body of studies on Chinese communication and/or business. ${ }^{2}$

b. Politeness' is usually less salient in ideological debates than impoliteness (see Kádár and Haugh 2013) - it is often the case that language users are more eager to discuss cases of inappropriate behaviour, which are socially controversial, than etiquette or other aspects of politeness. Thus, research that identifies forms of normative behaviour as 'Confucian', which is often the case in the

2. In addition, it is often not so much a specific linguistic action of (im)politeness that triggers evaluations, but rather the linguistic and non-linguistic interaction that surrounds a certain salient action (Kádár and Haugh 2013). 
field, ignores the point that the influence of Confucianism on interpersonal behaviour can perhaps be more clearly captured from the perspective of inappropriate behaviour, and the impolite evaluations that such behaviour triggers, i.e. cases when behavioural norms of Confucianism are saliently breached.

In sum, I believe that 'Confucianism' has limitations as an analytic notion if it is used uncritically, and I address this problem by attempting to find hard evidence for the fact that Confucian ideological influences play a part in actual evaluative practices occasioned by (in)appropriate behaviour, and that such practices reflect culture-specific tendencies.

\subsection{The scope of this study}

In order to show the effect of Confucian ideology beyond the conventional and/ or ritualistic aspect of interpersonal behaviour, I examine an interaction type which is arguably not culture-specific, and which is thus not clearly identifiable with Confucianism. I believe that a significant amount of Chinese interactions are similar to this: as I argued in the previous section, (in)appropriate behaviour in colloquial Chinese language very often does not seem to be particularly 'Confucian', and if there is an element of Confucianism behind colloquial Chinese it should be captured, before everything else, in terms of evaluative tendencies. In this chapter I examine a case of conflict in which the swearword gun 滚 'fuck off' is used in a classroom conflict - an expression and situation with equivalents in many languages and cultures - and I try to answer the question of whether this conflict reveals any hint of the operation of Confucianism as an underlying ideology, by examining its situated evaluations.

My goal is to create a simple model to capture the role of Confucian ideology in Chinese evaluations of (in)appropriate behaviour in certain interpersonal relationships, which are regarded as important in Confucianism. I point out that it is difficult to talk about the relationship between (in)appropriateness and Confucian ideology in a broad sense - instead, we need to identify a number of interpersonal relationships which are imbued with ideological perceptions and study the operation of ideology in interactions that take place in these particular relationships. My inquiry is centred on the notion of morality because ideological issues are often re-enacted in evaluation in relation to issues of (in)appropriateness and (im)polite evaluations (Kádár and Marquez-Reiter 2015). I define morality here as it is understood in a popular pan-cultural sense, i.e. the capability of distinguishing right from wrong.

My focus on specific, ideologically salient relationships within the nexus of interpersonal relationships accords with my stance that Confucianism should 
preferably not be used as an umbrella term. As my cross-cultural pragmatic inquiry makes clear (Section 3), evaluations of (in)appropriateness tend to follow patterns that are typical of the Chinese culture's perceptions of the given action situated in a given interpersonal relationship. Yet, it is difficult to evidence that a given action is evaluated extremely differently in the same interpersonal relationship in other cultures.

An important point to address before engaging with the present examination is 'why now?'. That is, considering that Confucianism was denounced during the Cultural Revolution (1966-1974) in China, it has only been re-introduced gradually and has been integrated into a complex intermix of ideologies, one may ask whether studying this theme bears relevance to language use/perception in Chinese society. It is necessary to point out, however, that although Confucianism as a formal ideology disappeared for a decade from Chinese public discourses (or emerged only in a negative sense), this 'ban' which was short-lived compared to the overall Chinese social history of Confucianism had limited influence: as Pan and Kádár (2012) point out, the examination of language use during the Cultural Revolution reveals that Confucianism continued to operate to some extent as an underlying notion even during this period. In addition, by now Confucianism has arguably been reintroduced as a national ideology, and as Zhang and Schwartz's (1997) insightful exploration reveals, it continues to exist in collective memory as the ordinary people's 'national heritage'. Thus, when one engages into the examination of Confucianism as a principle of Chinese interaction, one examines an alive and kicking phenomenon - and the intriguing question is: how can this phenomenon be captured on the level of language, without falling into the trap of making overgeneralisations.

\section{The case study \& data}

As a case study, I focus on a recent incident that has taken place in a secondary school in Huangchuan County, Xinyang, China, on 17/04/2015. A Chinese female student was sleeping during a history class and when the lecturer attempted to reprimand the student, she cried Gun! 滚 'Fuck off' at him. In turn, the lecturer grasped the student and hit her. After the student hit back, he dragged her to the front of the class and assaulted her, while the rest of the students did not dare to intervene.

The difficulty of this case study resides in the complexity of participant roles and the moral and behavioural expectations triggered by acting in these roles. On the one hand a student is clearly not expected to sleep during the class, not to mention swearing at the lecturer. On the other hand, Chinese law prohibits lecturers from assaulting students (e.g. Chen et al. 1997), even if the student 
behaves in a clearly inappropriate way. Yet, physical punishment continues to be implicitly present in the realm of Chinese education (e.g. Kelley and Tseng 1992; Schoenhals 1993).

Traditionally, the main method of discipline in China was to hit and beat students, sometimes quite severely. After 1949, as new teacher/student relationships were being advocated, beating and its practitioners came under heavy criticism. Beating is thus no longer the primary means of disciplining students, and many other methods have been adopted. Nonetheless, some teachers still use physical punishment to discipline their students. A seven-year-old American child who spent a year in primary school in China told me that teachers hit students on the wrist with a rod when they misbehaved. Another American, who spent a year in senior middle school in China, told me that one of his teachers carried a rod that she used to strike students' desks when they did not do their homework. She also yelled at students until they were almost in tears.

(Schoenhals 1993: 104)

This situation has changed in the 2000s (Sargent 2009), in that physical punishment has continued to disappear as a practice - although it still continues to lurk in Chinese schools - and therefore, a lecturer is now formally held accountable for any physical aggression that they commit. Yet, lecturers are also expected, in line with the Confucian ideology of education, to be strict, hence preserving the honour of their institutions (see Wang 2004; Hui 2005). As the popular Confucian saying goes, Yan-shi chu gao-tu 严师出高徒, i.e. 'a strict lecturer produces good disciples', while a person who is bu-jing-shizhang 不敬师长, i.e. 'who is disrespectful to lecturers and elders' is worthless. Thus, Chinese educational ideology is in transition: traditional Confucian norms continue to dominate school life and the lecturer is regarded as a figure of authority supposedly more than in Western education systems; at the same time, with increasing social focus on individuality this traditional perception is challenged (Jin and Cortazzi 2006). This change manifests itself in contradictory views on and evaluations of appropriate behaviour in the lecturer-student relationship (Sargent 2009) in Chinese social discourses.

Examining school incidents allows us to capture the role of Confucianism in (in)appropriate evaluative patterns in the teacher-student relationship: arguably those who take the lecturer's side and express their negative evaluation of the student's behaviour animate Confucian ideological stances, either implicitly or explicitly. Whilst taking the lecturer's side does not, by itself, imply a Confucian ideological attitude, people's evaluations are influenced by this normative ideology, and in certain cases, observers of such events even give voice to their views that (re-)introducing Confucianism to schools is important (see e.g. Example 9). The contrastive study of Chinese evaluative patterns with British/American ones when it comes to similar clashes between teachers and students (see Section 3.2) provides both qualitative and quantitative evidence for the correlation between Confucian 
ideology and Chinese evaluations of teacher v. student attitudes. More specifically, as the case study reveals, institutionally ratified commenters (authorities, news writers) tend to implicitly take the lecturer's side, while they also attempt to suit the modern requirement of a student's right to protection. This clearly differs from Western reports, which foreground the lecturer's inappropriate behaviour in such scenarios. This implies that the student's inappropriate behaviour is more visible in the Chinese education context than in its Western counterpart, due to the moral contradiction between student aggression and Confucian ideals of appropriate behaviour. This finding is also reflected by ordinary evaluators (online commenters) who shared their views on the event with others online. Furthermore, in the Chinese case, the lecturer's physical action is not unanimously evaluated as negative, i.e. there are occasional clashes between older and younger generation commenters. This seems to us to illustrate a conflict between traditional (Confucian) and modern (globalised) ideological values.

The case study is drawn from a small database of 5 Chinese and 5 North American incidents of abusive behaviour in high schools, in the course of which a lecturer physically assaults a student. For the sake of comparability, I only studied cases in which the lecturer's physical move is preceded by the student's clearly abusive behaviour, i.e. incidents in which a complex issue of morality is involved (Henry 2000), and did not study cases in which it is clearly the lecturer who is abusive.

My inquiry focuses on the following data types:

Institutionally ratified evaluations:

- The actual video recordings of the events;

- Reports written by authorities and/or newspapers; Ordinary evaluations:

- Online comments on the videos on video sharing websites such as Youku in China and YouTube.

I use Goffman's (1981) notion of 'ratification' to refer to the assumed right of powerful personae and organisations to evaluate events as (in)appropriate. I have examined altogether 27 (news) reports on the incidents, in order to compare the way in which Chinese and Western (British/American) institutionally ratified sources represent/construct the identities of the lecturers and students involved, hence conveying an implicit evaluation of the verbal and non-verbal behaviour involved in the incidents. For popular ('ordinary' commenter) observations, I have examined altogether 318 comments in Chinese and 252 comments in English.

On the methodological level, the analyses of institutionally ratified and ordinary commenter data requires different approaches. Capturing evaluative stances 
in monologic institutionally ratified reports can be done in various ways, including e.g. research on evaluative lexis, adverbial marking of stances, the research of narratives, and so on (see an overview in Hunston and Thompson 1999). As my research is involved in morally-loaded incidents, I pursue an interest in evaluative representations of moral responsibility and agency (cf. Harris et al. 2006; and Kádár and Marquez Reiter 2015); examining morality also involves studying issues such as the parties involved in the incident (only the dyad of the teacher and students, or other personae with potential moral responsibility), and descriptions of the student's personal circumstances as reasoning for their behaviour. My focus on morality entails a discourse analy tic approach to implicitly evaluative language used in monologic texts, and other analytic issues such as information structure within the narrative (Brown and Yule 1983; i.e. whether the student's or the lecturer's responsibility is mentioned first). When it comes to ordinary evaluations, evaluative stances are more explicit and moral principles are occasionally evoked in a direct way - consequently, the evaluative and cross-cultural analysis of this data is more straightforward. I have undertaken both qualitative and quantitative analyses of the institutionally ratified and ordinary commenter datasets, and have compared the findings across these datasets.

My focus of analysis on (im)polite evaluations is different from discursive approaches to politeness (see e.g. Watts 2003; Linguistic Politeness Research Group (ed.) 2011), in that in the present analysis I aim to look beyond evaluative moments in the dyadic interactions between lecturers and students due to my ideological interest (cf. Section 1). In the discursive approaches politeness and impoliteness are generally examined in punctuated interactions, as it is being interactionally (co-) constructed by speech partners; this uptake entails analytic a micro-level focus on (im)politeness. Examining lay observer evaluative tendencies has helped me to go beyond the micro-level and to be able to make more general claims about understandings of (in)appropriate and subsequent (im)politeness behaviour, without setting out from a priori overgeneralisations.

\section{Analysis}

Let us first represent the interaction between the lecturer and the misbehaving student featured in our case study, in a transcribed form:

（1）（标题：河南信阳潢川县彭店中学男老师打女学生。

语境: 一男教师正在上课, 一女生在睡觉发出声音, 所以老师过去提醒她, 但女 生说了一个字“滚”! 于是男教师用书本打女生的头。) 
1. 男教师：你想千什么!

2. 女生反抗并说: “你有病啊” [双方扭打起来]

3. 男教师：你真是太不像话了!

4. 女学生：你有毛病啊!

5. 男教师: 你站那里别动!

6. 女学生: 咋呀! (千什么!)

7. 男教师: 你在千嘛呢!

8. 男同学: 您先坐会儿, 你先坐会儿。

(A male lecturer in Pengdian Secondary School in Xinyang Hunagchuan County of Henan Province beats a female student in class.

Context: A girl is sleeping in class, and the lecturer approaches her and attempts to wake her up. In response, the girl utters 'Fuck off!' and the lecturer smacks her head with the coursebook.)

1. Lecturer: What do you think you're doing?!

2. Female student: You're nuts!

[They grapple with each other.]

3. Lecturer: You're really crossing the line!

4. Female student: You're sick!

5. Lecturer: Stand still, don't move!

6. Female student: What?! (Do what?!)

7. Lecturer: What did you do?!

8. Male student: Sir, just take a seat. Just take a seat.

[The lecturer pushes the student close to his desk and knocks her down. The student continues to swear and scream from the floor.]

(Retrieved from: https://www.youtube.com/watch?v=r3g1wyl1MkM)

On the linguistic level it is clearly the student who acts improperly - following the first gun 'fuck off', in lines 2 and 4 she claims that the lecturer is 'sick' (Ni you bing $a$ 你有病啊) and that he is a 'weirdo' (Ni you maobing $a$ 你有毛病啊). ${ }^{3}$ Note that she addresses the teacher by using the direct second person pronoun $n i$ 你, which is formally prohibited in Chinese schools - a student must address her or his teacher by using the professional form of address laoshi 老师 ('teacher'), and even the indirect second person pronoun nin 您 is unacceptable if it is used without this form of address (see Lü 1985). This increases the impact of the student's abusive behaviour. However, most of this conversation takes place after the lecturer hits

3. Note that due to my lack of command of the dialect involved, I use the standard Mandarin pinyin transliteration throughout the paper. 
the student on the head with a book, hence crossing an important line, as corporal punishment is prohibited in Chinese schools. It is pertinent to note, however, that the situation is ambiguous, in that the teacher hits the student with a light book (rather than with hand or fist), which can be interpreted as a ritualistic move inherited from Chinese history. Hitting a student with the item she is supposed to use - her book - may represent the teacher's simultaneous frustration and wish to aid the student, and Chinese lecturers used to make such moves before the current legal prohibition of taking physical actions against students (see e.g. various historical stories in Watson 1999). Combining this with the fact that the student has been regarded as 'problematic' for some time by various teachers and students (see Section 3.1), it is possible to argue that the lecturer's intention was supposedly to restore the normative order within the classroom instead of escalating the situation. However, following the continuous offenses in the course of the interaction, the lecturer finally moves beyond what is regarded as acceptable in a modern Chinese classroom, as he drags the student towards his desk, and as the student attempts to hit back he knocks her down (although this 'knocking down' is relatively gentle, as the student continues to swear and scream from the floor).

\subsection{Institutionally ratified representations and evaluations of the event}

The video recorded interaction by itself reveals little information on the role of Confucian educational ideology in the evaluation of the lecturer's and the students' behaviour. While one could argue that the lecturer's increasing frustration is due to the fact that his traditional (Confucian) role as a lecturer is challenged by the student, arguably any person whose authority is rejected and who is being offended in public would feel offended, irrespective of culturally-situated ideologies. Thus, the evaluative moment in the interaction by itself does not offer much help for our present research.

The situation changes if one looks into the way in which the Xinyang County authority reports the event, as represented in the news:

（2）关于彭店中学教师与学生发生肢体冲突事件的通报

2015年4月17日下午, 彭店中学发生一起教师与学生肢体冲突的事件。经潢川县 教体局调查, 此事系教师王某因学生小玲 (化名) 课堂大声喧哗, 前去制止, 小 玲出言冲撞老师, 双方发生肢体冲突。

彭店中学表示, 事件发生后, 校方立即与该学生家长取得联系, 并与当事学生, 学生家长, 当事教师一起前往潢川县人民医院对学生身体情况进行了详细的调 查。在确认学生身体健康没有影响的情况下, 学生与家长已对学校和当事教师 表示谅解。

潢川县教体局表示, 该事件中教师未能对学生的课堂违纪及辱骂教师行为进行 冷静处理, 有违教师行为规范准则。目前, 学校已责令涉事教师停课, 并将根据 调查情况, 对相关责任人作出进一步处理。 
Official report on the fight incident between a teacher and a student at Pengdian Secondary School

In the afternoon of 17 April 2015 a fight broke out between a teacher and a student at Pengdian Secondary School. According to the Educational Bureau of Huangchuan County's investigation, this was due to the fact that the student, Xiaoling (name altered) was swearing loudly in the classroom, and as the teacher attempted to stop her, Xiaoling verbally abused him, and then both of them engaged in a fight.

Pengdian Secondary School pointed out that after the incident it immediately informed the parents of Xiaoling, and the students, the parents and the teacher proceeded together to the People's Hospital at Guangchuan where the student's condition was carefully examined. After it was confirmed that the student did not suffer any injury, the student and the parents expressed to the school and the teacher that they wished to disregard the physical clash that took place.

The Educational Bureau of Huangchuan County pointed out that the teacher was unable to resolve the student's abusive behaviour in a calm way, hence violating the lecturers' behavioural principle. The School has already suspended the teacher and forwarded this matter to the higher authorities for further investigation. ${ }^{4}$

(Retrieved from: <http://news.xyw.gov.cn/news/xy/201504/00084774.html>)

The present report is institutionally ratified as it has been written by the authorities; importantly, I found it embedded into a news article on Xinyang Net (Xinyang wang 信阳网), which is an online news website operated by the Chinese Government, and so the news item, and other news reports on the event, reflect the authorities' view of the event. Therefore, although this is a seemingly 'objective' report, from the discourse analyst's perspective it includes various evaluative stances, and if one looks into these evaluative stances it is clear that they reflect Confucian ideologies that underlie education:

- On the information structural level, the first paragraph of the narrative focuses on the student's improper behaviour: it draws attention to the student's violent behaviour and the teacher's action is clearly toned down as a reaction. It is worth noting that there is a discrepancy between on-site observer accounts, the video recording and the report. It is clear in the video that the student was sleeping and the conflict broke out as the lecturer attempted to wake her up.

我是该班学生之一, 该女生性格怪异, 暴躁, 平时经常上课睡觉, 学习成绩也较 差。事发当时该女生就在睡觉, 老师意图叫醒, 却反遭辱骂, 随手抄起课本扔向 老师, 后扭打起来。

4. This and the subsequent translations have been made by me. 
I am one of the students of this class, this girl is highly problematic and violent, she often sleeps during classes and her results are very low. At that time the girl was sleeping, and as the teacher attempted to wake her up she verbally abused him immediately, and also threw her textbook towards the teacher, and the fight broke out after that. (Zhuatieba)

(Retrieved from: http://www.zhuatieba.com/video/XOTM3MzQ1ODUy)

It is not worth speculating about whether this discrepancy between the official report and the informal comment is intentional or not, but it is evident that it increases the female student's moral accountability for the outbreak of the conflict - a lecturer is meant to intervene if a student is behaving violently during classes, whilst waking up a sleeping student is a morally right but not compulsory decision (on moral responsibility and compulsory action see Kass 1990). These references to the lecturer's passive role and his compulsory action implicitly restore the teacher's higher moral status, hence reflecting a Confucian ideological stance, and they also express a clearly negative evaluation of the student's action. Note that the student's actual swearword 'fuck off' is tactfully omitted (see the analysis of Example 3 below). In addition, the source does not specify who struck first.

- The second paragraph also reinforces this implicit evaluative stance: this section points out that the student did not receive any injury, and that she and her parents told the lecturer and the school that they wished to disregard the event. Importantly, in Chinese culture, disregarding an incident is an important decision, as it is interpreted as admittance of responsibility/wish to reconcile, and reference to this fact again restores the teacher's honour in the situation.

- It is worth noting that in the account, the fact that the student is a female is not mentioned (although the reader can infer gender from the pseudonym): when it comes to her injuries, there is no indication of her gender, even though a number of online commenters condemned the lecturer for physically assaulting a female student (see also the analysis of (3) below). It is fair to note here that in Chinese, unlike in the case of English he/she, it is not grammatically compulsory to indicate a person's gender in the third person. However, in modern Chinese media, gender is often distinguished in writing ( $t a$ 他 form for masculine and $t a$ 她 form for feminine); in the report, however, no such gendered pronoun is used, and the female student is referred to by the gender-neutral nominal form xuesheng 学生 (student).

- Finally, it is only paragraph 3 which points out that the lecturer failed to act according to his professional role. But even this section draws attention repeatedly to the student's abusive behaviour, i.e. the moral responsibility is indirectly attributed to the student. 
- In the course of the report no other students are mentioned, which indicates that it was only the student's behaviour that upset the order in the classroom, and that the teacher's action helped to restore normative order. This is clearly different from the English report on the event (Example 3).

The evaluative stance of this report becomes evident if one compares it with the English language report on the event, published in the Daily Mail (21 April 2015). Note that this is not an entirely fair comparison: an official document like (2) above has the implicit goal of being objective, and it also intends to avoid stirring up controversies. A tabloid like Daily Mail, on the other hand, has a very simple agenda: it aims to create controversies in order to increase selling figures. Yet, it is interesting to make this comparison for three reasons:

- First, in terms of participation status both official reports and newspaper articles represent ratified stances, and as such they represent ideologies that they regard as normative from the public's perspective.

- Second, it is important to point out that the way in which the information is structured and evaluative stances are represented in the Daily Mail are also present in more formal British-American sources on school aggression between lecturers and students, although in less dramatised forms. Thus, while the Daily Mail itself is not an official report, in terms of positioning moral responsibility and other features it illustrates the cross-cultural differences that characterise my broader dataset.

- Third, in a strict sense there is no report material that absolutely 'represents' unanimous governmental views - unless a report is a government's official communiqué, there is always a potential discrepancy between the ways in which various bodies or representatives evaluate the appropriateness of an event. Thus, a government newspaper's view does not automatically mean that this view 'mirrors' or 'voices' that of the Government (in fact, government media are repeatedly sanctioned for violations in that sense). This implies that the comparison of the Chinese and English representations of the same event is not as far-fetching as it may seem at first glance.

It is here worth citing some parts of the Daily Mail report:

(3) Classroom discipline, Chinese style: 5 Shocking video shows teacher repeatedly hitting girl, 14 - because she talked without permission

5. It is worth noting, for readers outside of the British context, that the Daily Mail is a tabloid with occasional racist/anti-foreign stances, and the exceptionally dramatic representation of the event in the newspaper might be partly due to the fact that the newspaper tends to emphasise the supremacy of British education over other educational systems. 
- Man hit and stamped on girl who shouted at him when told to stop talking

- Shocked students can be heard crying while others try to intervene

- Teacher suspended while local education authority investigates

- Incident caught on camera has split public opinion online in China

This dramatic footage shows the moment a history teacher hits a female student with a textbook then stamps on her, during a classroom fight in China. The shocking video clearly shows Mr Wang strike out at teenager Gao while she is seated, and then again as she starts to stand up, after she shouted at him when asked to stop talking.

Seconds later, he pushes the girl to the ground and can be seen stamping on her in front of shocked classmates.

[...] the minute-long clip, filmed by another pupil in class secretly, has sparked debate on social media with many condemning the teacher for unacceptable violence, particularly towards a female pupil [...]

A few male students stood up to intervene while most of the class froze in fear and others can be heard crying in the background.

(Retrieved from: http://www.dailymail.co.uk/news/peoplesdaily/ article-3048799/Classroom-discipline-Chinese-style-Shocking-videoshows-teacher-repeatedly-hitting-girl-14-talked-without-permission.html)

The following are obvious differences between Examples (2) and (3):

- In the English version the aggressive party is the lecturer who "hit and stamped on" the student without being provoked; the article uses various expressions such as "shocking video" and "dramatic footage", which increase the lecturer's moral accountability;

- The lecturer's suspension is mentioned right at the headline summary;

- The student's gender ("female student") is emphasized twice in the narrative;

- The other students' reactions (fear and intention to intervene) is a recurrent theme in the report.

It is a noteworthy fact that there are some mistranslations in the English text, which further increase the difference between the Chinese and the Western representations of the event. For example, the Daily Mail notes that

(4) A statement said the student, her parents, the teacher and the school had come to an understanding over the matter.

This simply implies that the parties came to a settlement that they do not wish to disclose (incl. the possibility of financial compensation). However, the Chinese original report (Example 2) uses the expression biaoshi-liangjie 表示凉解, which does not simply mean 'expressing understanding', but rather the intention to 
disregard a conflictive event (see the analysis above). That is, it implies that the student and the family are aware that the student is at least partially responsible for the event, which is also confirmed by the fact that it is the student and the family who express to the school this intention to disregard the event (学生与家长 已对学校和当事教师表示凉解 'the student and the parents expressed to the school and the teacher that they disregard the physical clash that took place'). A perhaps even more striking translational issue is the way in which the swearword used by the student is represented in the English text; The Daily Telegraph notes that:

(5) Gao shouted 'get out' then our teacher hit Gao hard with a fist.

Gun is a swearword, which should be translated as 'fuck off', and so this translation seems to decrease the gravity of the student's behaviour.

To sum up, on the institutionally ratified level (reports), there seem to be some salient differences between the Chinese and English reports on the same event, and these differences, summarised by Table 1, apply to other cases in the dataset.

Table 1. Differences between ideological stances in Chinese and English reports on school violence

\begin{tabular}{|c|c|c|c|c|}
\hline & $\begin{array}{l}\text { Agency/moral } \\
\text { responsibility }\end{array}$ & Parties affected & $\begin{array}{l}\text { The student's } \\
\text { personal } \\
\text { circumstances } \\
\text { (gender, family } \\
\text { background, } \\
\text { etc.) }\end{array}$ & $\begin{array}{l}\text { Representation } \\
\text { of the order of } \\
\text { events }\end{array}$ \\
\hline $\begin{array}{l}\text { Chinese reports } \\
\text { (14) }\end{array}$ & the student 14 & $\begin{array}{l}\text { only the lecturer } \\
\& \text { the school, } \\
\text { and the student } \\
\& \text { family } 11 \\
\text { also other } \\
\text { classmates } 13\end{array}$ & $\begin{array}{l}\text { unmentioned } 9 \\
\text { mentioned } 5\end{array}$ & $\begin{array}{l}\text { the student's } \\
\text { abusive } \\
\text { behaviour } \rightarrow \\
\text { outcome of } \\
\text { the clash (e.g. } \\
\text { the lecturer's } \\
\text { suspension) } 14\end{array}$ \\
\hline $\begin{array}{l}\text { English reports } \\
\text { (13) }\end{array}$ & the lecturer 13 & $\begin{array}{l}\text { not only the } \\
\text { students and the } \\
\text { lecturer but also } \\
\text { other classmates } \\
13\end{array}$ & mentioned 13 & $\begin{array}{l}\text { the outcome of } \\
\text { the event (e.g. } \\
\text { the lecturer's } \\
\text { suspension) } \rightarrow \\
\text { the student's } \\
\text { inappropriate } \\
\text { (rather than } \\
\text { abusive) } \\
\text { behaviour } 13\end{array}$ \\
\hline
\end{tabular}


Whilst arguably this dataset is way too small to make any generalisation, it is safe to argue on the basis of such major representational differences that clashes between lecturers and students tend to be evaluated on the institutionally ratified level differently in Chinese and British-American reports. Importantly, these are not clear-cut cross-cultural differences: we are only talking about evaluative tendencies, and the Chinese sources are not unanimous on certain points, e.g. some reports mention the negative effect of the clash on other students even though the majority of sources remain silent about this issue. Instead of putting this difference under the 'cultural umbrella', it is worth approaching it from the perspective that reports are meant to be 'politically correct'. In the West, in particular in Englishspeaking countries, while a lecturer is certainly a reputed figure, this profession has no specific ideological history that distinguishes it from other socially important jobs such as doctors or nurses (see Etzioni 1969). In addition, since around the 1960s there has been an increasing number of conversations on student rights in various countries in Europe and beyond (Johnson 1997) - i.e., from an ideological point of view the teacher is held morally accountable for any mutual physical clash.

The analysis so far has illustrated that institutionally ratified evaluations of this interaction are influenced by Confucian ideology. In terms of (in)appropriateness, whilst both the student's and the lecturer's behaviours are evaluated as inappropriate, the degree of these evaluations differ between Chinese and English reports due to the different perceptions of moral accountability involved (Kádár and Marquez Reiter 2015). In other words, insofar as we interpret 'appropriateness' as an act that triggers positive feelings and polite evaluations, and 'inappropriateness' as one that triggers negative feelings and a sense of impoliteness, it can be argued that in the Chinese case the student's act of swearing at the teacher, and her subsequent actions are evaluated as more saliently inappropriate than in the West, due to the Confucian ideology that underlies the specific interpersonal relationship between teacher and student.

\subsection{Ordinary representations and evaluations of the event}

Ordinary online evaluations of the event made by posters are more diverse than their high-ratified counterparts, as the comparison of Table 1 with the following Table 2 reveals.

Table 2 includes the figures of the whole ordinary representation dataset. In what follows, I refer to these figures but only cite comments on the actual case study examined in the paper. 
Table 2. Differences between ideological stances in Chinese and English comments on incidents of school violence

\begin{tabular}{|c|c|c|c|c|}
\hline & $\begin{array}{l}\text { Agency/moral } \\
\text { responsibility }\end{array}$ & Parties affected & $\begin{array}{l}\text { The student's } \\
\text { personal } \\
\text { circumstances } \\
\text { (gender, family } \\
\text { background, etc.) }\end{array}$ & $\begin{array}{l}\text { Representation } \\
\text { of the order of } \\
\text { events }\end{array}$ \\
\hline $\begin{array}{l}\text { Chinese } \\
\text { comments (318) }\end{array}$ & $\begin{array}{l}\text { the student } 245 \\
(77 \%)^{6} \\
\text { the lecturer } 73 \\
(23 \%)\end{array}$ & $\begin{array}{l}\text { discussing the } \\
\text { student and } \\
\text { the lecturer } 274 \\
(86 \%) \\
\text { mentioning } \\
\text { other students } \\
44(24 \%)\end{array}$ & $\begin{array}{l}\text { not mentioned } \\
198(62 \%) \\
\text { mentioned } 120 \\
(38 \%)\end{array}$ & $\begin{array}{l}\text { N/A (most of the } \\
\text { comments are } \\
\text { relatively brief) }\end{array}$ \\
\hline $\begin{array}{l}\text { English } \\
\text { comments on } \\
\text { incidents in } \\
\text { the UK/North } \\
\text { America (252) }\end{array}$ & $\begin{array}{l}\text { the student } 121 \\
(48 \%) \\
\text { the lecturer } 131 \\
(52 \%)\end{array}$ & $\begin{array}{l}\text { discussing the } \\
\text { student and the } \\
\text { lecturer } 123 \\
(49 \%) \\
\text { mentioning } \\
\text { other students } \\
129(51 \%)\end{array}$ & $\begin{array}{l}\text { unmentioned } 92 \\
(36 \%) \\
\text { mentioned } 160 \\
(64 \%)\end{array}$ & N/A \\
\hline
\end{tabular}

In terms of agency and moral responsibility, there are Chinese commenters who emphasise the lecturer's responsibility for the outbreak of the conflict. For example, a commenter on the Youku website makes the following note:

（6）老师就是教育学生的, 就算学生有不对的地方, 作为老师你应该用思想教育她, 而不是用巴掌去打学生

A teacher's job is to educate students, and if there is an area that is wrong with a student the teacher needs to carefully educate them, instead of slapping them on the face

(Retrieved from: http://v.youku.com/v_show/id_XOTM2ODAzMzQw. html?from=s1.8-1-1.2)

Note that while there is no evidence that generation determines the nature of these evaluations, as in the majority of cases there is no information on the age of the posters, there are occasional clashes between older and younger generation commenters, in that younger posters argue that from their generation's point of view the fault is that of the teacher. ${ }^{7}$ Example (7) illustrates this phenomenon:

6. As the present study is based on a relatively small dataset, and also for the sake of simplicity, we use round figures instead of decimals.

7. On Chinese (im)politeness and generation see $\mathrm{He}(2012)$. 
（7）你一个大老爷们, 跟个小姑娘较什么劲? 建议学校立即开除这老师。小孩子不 懂事你平时怎么不教育? 脾气大当什么老师! 小姑娘跟你多大仇? 这样往坏里 打? 学生不好学, 别以为你们当老师的一点责任也没有。现在有些老师真的素 质太差, 满口脏话, 酗酒赌博俱全, 难为师表, 真是为我过的未来担忧呵! 这老 师真太不理智了。

You, old people, why do you match your strength with a little girl? The school should expel this teacher immediately. If a small child doesn't understand something, why don't you just teach her? With such a violent temper, what kind of teacher can one be? What kind of big harm did this little girl cause you? Did you really have to beat her up? If a student doesn't perform well, don't think that you have no responsibility at all. Nowadays there are some teachers whose quality is really poor, who use obscene language, who are alcoholic, gamble and do all kinds of stuff, who can't act as an example figure to students at all, and this makes me feel concerned about my future! This teacher is so unreasonable.

(Retrieved from: http://v.youku.com/v_show/id_XOTM2ODAzMzQw. html?from=s1.8-1-1.2)

This poster emphasises the generational issue by referring to the student as xiaoguniang 小姑娘 'little girl', and by expressing concern about the future of the Chinese youth.

The majority (77\%) of the commenters, however, argue that the student is the morally accountable person in the given situation, as the following comment illustrates:

（8）学生在不应该也不能这样! 真是没人性

A student can't be and shouldn't be like this! She is a real subhuman

(Retrieved from: http://v.youku.com/v_show/id_XOTM2ODAzMzQw. html?from $=$ s1.8-1-1.2)

In addition, there is a recurrent argument within this group of comments that China should return to its Confucian roots in terms of education:

（9）学生犯错叫违纪, 老师犯错叫违法, 现在的孩子太那个啦! 中国现在应该拾起 孔子时期的教育方式, 应该学学现在的日本和韩国的教育方式。

If a student makes a mistake it is called breaking a rule, if a teacher does so it is called breaking the law - students in these days really lack quality! China must now get back to the educational methods of Confucian times and study the ways in which the Japanese and Koreans educate.

(Retrieved from: http://v.youku.com/v_show/id_XOTM2ODAzMzQw. html?from $=$ s1.8-1-1.2) 
This group of comments is noteworthy because posters like the writer of (9) explicitly refer to Confucian ideology.

If one looks at the figures of Table 2, it becomes clear that Chinese posters are far from being unanimous on the evaluation of this clash. This seems to us to indicate a contest between traditional Confucian and modern Chinese ideologies of education; a typical example, along with the explicit generational issue, is the emphasis on the gender issue involved. In the (implicitly) Confucian interpretation of the event (see Example 2) the student's gender is insignificant, as the emphasis is on the teacher - student (shi-tu 师徒) relationship, rather than the personal characteristics of the student; it is not a coincidence that Chinese commenters who support the lecturer do not usually touch on the gender matter. Critical commenters, on the other hand, often refer to the unchivalrous character of the lecturer and, occasionally, other students who failed to intervene. Importantly, this notion of chivalry (men protecting unrelated women irrespective of the context of an incident) is a Judeo-Christian ideological notion, which has recently been 'imported' into China (see more in Kadar and Marquez Reiter 2015), and so referring to it represents a contest between traditional and modern ideologies. The following example illustrates this phenomenon:

（10）男同学若勇敢点及时制止, 事后别说那女学生, 这个老师若是稍微懂点事理也 会感激难学生//@圈外看热闹:这班男生太怂了。遇到家暴, 男的打老婆或者女 朋友, 路人都会上前制止。课堂上, 中年男老师打女同学还不做声

If the male classmates were just a little bit brave they should have intervened immediately. They shouldn't say things like "if that girl student and this teacher were slightly more reasonable they would have resolved the student's difficult situation"//@Being a helpless bystander: these male classmates are chickens. If people see family abuse, like when a guy beats up his wife or girlfriend, the ordinary people on the street are going to intervene. But when they see that their girl classmate is being beaten up by a middle aged male teacher, they do not dare even to make a noise

(Retrieved from: http://www.zhuatieba.com/video/XOTM3MzQ1ODUy)

Yet, while the figures in the Chinese data show diversity, it is pertinent to compare it with English comments on similar incidents in the UK/North America, as this comparison reveals some cross-cultural differences in terms of evaluative tendencies. In terms of moral responsibility, $77 \%$ of the Chinese comments put moral accountability on the aggressive student for the outbreak of the event, whilst in the English data this is only $48 \%$. In other words, in the Chinese ideological context the student's impolite/inappropriate behaviour is evaluated more saliently than in its British/US counterpart. In a similar way, in the Chinese data $86 \%$ of the commenters discuss the matter within the dyad of the teacher-student 
relationship, and comments like (10) are relatively rare, whereas in the English data this figure is only $49 \%$; this difference seems to us to represent the traditional Chinese ideological emphasis on the master-disciple relationship, which is far less important in Western cultures. In terms of impoliteness, the breaking of this relationship is more salient in the Chinese culture than in its British/North American counterpart. Finally, $62 \%$ of the Chinese commenters do not mention the female student's vulnerable background, which indicates that personal/social matters are less likely to be treated as an excuse for offending one's teacher, i.e. the traditional relational dyad of the teacher and disciple overrides other factors. This is different in the English data in which $64 \%$ of the commenters discuss - either positively or negatively but definitely as an explanation - the misbehaving student's personal/ social background.

\section{Conclusion}

In the present paper I have argued that Chinese (in)appropriate evaluations (and the potential sense of (im)politeness such evaluations trigger) cannot be directly linked with 'Confucian' ideology, without the risk of using this notion as an umbrella term. As (in)appropriateness comes into existence in the form of evaluation, it is problematic to attempt to utilise only formal and/or recurrent elements of language use, such as rituals of invitation, as evidence of the 'Confucian' character of Chinese language use. In addition, the evaluation of various interactional events, such as the case study analysed in this paper, come into existence in the form of intricate discourses and metadiscourses, i.e. one cannot always capture the relationship between (in)appropriateness (and (im)politeness) and ideology on the dyadic interactional level (see more on this issue in Haugh and Kádár forthcoming). Furthermore, in order to capture the effect of a particular culturally-situated ideology on (in)appropriate evaluations, it is useful to analyse incidents that trigger morally-loaded discourses and metadiscourses, as morality and ideologies of (in)appropriateness (how to treat others) are strongly connected (see Kádár and Márquez Reiter 2015).

The present paper is mainly limited to a single case study, and in this sense the findings should be further attested by using more illustrative data. Yet, I also adduce quantitative comparative data, the results of which have revealed that the findings represent Chinese understandings of appropriate behaviour in a broader sense. Another limitation of the present study is that I have not examined Chinese reactions on Western school incidents, in spite of the fact that such reflections would also reveal information about Chinese understandings of appropriateness. As the present paper has focused on the operation of Chinese evaluative stances 
in their own cultural surroundings, I believe that once the data had to be limited because of space, it has been justifiable to examine domestic Chinese incidents.

In my view, it is difficult to talk about the effect of Confucianism on Chinese evaluative attitudes per se, as even if this ideology influenced every segment of Chinese interpersonal interaction - which it does not - it would be problematic to evidence such a relationship. Instead, I believe that it is more productive to look into evaluative attitudes in certain interpersonal relationships, which have salience in the Confucian ideology, such as the teacher-student relationship studied in this paper. The quantitative data discussed in Section 3 of this paper have shown that as far as we focus on such relationships, cross-cultural differences can be captured in evaluative tendencies between Chinese and English. Yet, it is important to repeatedly emphasise that I am talking about tendencies here, and also that these tendencies may only apply in such an ideologically salient relationship. Putting it simply, while for example being rude to one's teacher is more morally condemnable in China than in the West, swearwords like 'fuck off' would perhaps be evaluated largely in the same way across cultures, once they are used outside of the given relationship. The present paper has only inquired into a specific interpersonal relationship, and it is subject to future research to prove whether Confucian ideology influences evaluative tendencies in other interpersonal relationships, and if yes, in which way.

At the present stage, however, it is possible to conclude this paper with the claim that evidence can be found for the existence and importance of Confucianism in evaluations of (in)appropriateness in Chinese.

\section{References}

Bell, Daniel A. 2010. China's New Confucianism: Politics and Everyday Life in a Changing Society. Princeton, NJ: Princeton University Press.

Brown, Gillian, and George Yule. 1983. Discourse Analysis. Cambridge: Cambridge University Press.

Brown, Penelope, and Stephen C. Levinson. 1987. Politeness: Some Universals in Language Usage. Cambridge: Cambridge University Press.

Bucknall, Kevin. 2002. Chinese Business Etiquette and Culture. Retrieved from: http://www.authorsden.com/sampleworkspdf/22275.pdf

Cameron, Deborah. 2004. "Out of the Bottle: The Social Life of Metalanguage." In Metalanguage: Social and Ideological Perspectives, ed. By Adam Jaworski, Nikolas Coupland, and Daríusz Glasínsky, 311-322. Berlin: Mouton de Gruyter.

Chan, Wang-Tsit. 1963. A Sourcebook of Chinese Philosophy. Princeton: Princeton University Press.

Chen, Xinyin, Qi Dong, and Hong Zhou. 1997. "Authoritative and Authoritarian Parenting Practices and Social and School Performance in Chinese Children." International Journal of Behavioral Development 21 (4): 855-873. 
Eelen, Gino. 2001. A Critique of Politeness Theories. Manchester: St Jerome.

Etzioni, Amitai (ed.). 1969. The Semi-Professions and Their Organization. New York: Free Press. Fang, Tony. 1999. Chinese Business Negotiating Style. London: Sage.

Fukuyama, Francis. 1995. "Confucianism and Democracy." Journal of Democracy 6 (2): 20-33. Goffman, Erving. 1981. Forms of Talk. Philadelphia: University of Pennsylvania Press.

Gu, Yueguo. 1990. “Politeness Phenomena in Modern Chinese." Journal of Pragmatics 14: 237-257. Harris, Sandra, Karen Grainger, and Louise Mullany. 2006. “The Pragmatics of Political Apologies.” Discourse \& Society 17 (6): 715-737.

Haugh, Michael, and Dániel Z. Kádár. 2016 forthcoming. The Metapragmatics of (Im)Politeness. Amsterdam and Philadelphia: John Benjamins.

He, Amy Yun. 2012. "Different Generations, Different Face? A Discursive Approach to Naturally Occurring Compliment Responses in Chinese." Journal of Politeness Research 8 (1): 29-51.

Henry, Stuart. 2000. "What is School Violence? An Integrated Definition." The Annals of the American Academy of Political and Social Science 567 (1): 16-29.

Hong, Beverly. 1985. "Politeness in Chinese: Interpersonal Pronouns and Personal Greetings." Anthropological Linguistics 27 (2): 204-213.

Huang, Yongliang. 2008. "Politeness Principle in Cross-culture Communication." Retrieved from: http://www.ccsenet.org/journal/index.php/elt/article/view/515/497

Hunston, Susan, and Geoff Thompson (eds.). 1999. Evaluation in Text: Authorial Stance and The Construction of Discourse. Oxford: Oxford University Press.

Hui, Leng. 2005. "Chinese Cultural Schema of Education: Implications for Communication between Chinese Students and Australian Educators." Issues in Educational Research 15 (1): 17-36.

Jin, Lixian, and Martin Cortazzi. 2006. "Changing Practices in Chinese Cultures of Learning." Language, Culture and Curriculum 19 (1): 5-20.

Johnson, John W. 1997. The Struggle for Student Rights: Tinker v. Des Moines and the 1960s. Lawrence: University of Kansas.

Kádár, Dániel Z. 2007. Terms of (Im)Politeness. Budapest: Eötvös Lorand University Press.

Kádár, Dániel Z. 2013. Relational Rituals and Communication: Ritual Interaction in Groups. Basingstoke: Palgrave Macmillan.

Kádár, Dániel Z., and Michael Haugh. 2013. Understanding Politeness. Cambridge: Cambridge University Press.

Kádár, Dániel Z., and Rosina Márquez Reiter. 2015. “(Im)politeness and (Im)morality: Insights from Intervention.” Journal of Politeness Research 11 (2): 239-260.

Kádár, Dániel Z., and Rosina Márquez Reiter. forthcoming. Leveraging Relational Practices. Cambridge: Cambridge University Press.

Kass, Leon R. 1990. "Practicing Ethics: Where is the Action?" Hastings Center Report 20 (1): 5-12. Kecskes, Istvan. 2013. Intercultural Pragmatics. Oxford: Oxford University Press.

Kelley, Michelle L., and Hui-Mei Tseng. 1992. "Cultural Differences in Child Rearing: A Comparison of Immigrant Chinese and Caucasian American Mothers." Journal of CrossCultural Psychology 23 (4): 444-445.

Li, Tianbo, and Gillian Owen Moreira. 2009. The Influence of Confucianism and Buddhism on Chinese Business: A Case of Aveiro, Portugal. Retrieved from: http://www.immi.se/intercultural/nr19/tianbo.htm

Linguistic Politeness Research Group (ed.). 2011. Discursive Approaches to Politeness. Berlin: Mouton de Gruyter.

Low, K. C. Patrick. 2010. "Confucius, Customer Service, and Service Excellence." Conflict Resolution \& Negotiation 4: 53-61. 
吕叔湘 Lü, Shuxiang 1985. 近代漢語指代詞 Jindai hanyu zhidaici [The pronouns of vernacular Chinese]. Shanghai: Xuelin chubanshe.

Pan, Yuling. 2000. Politeness in Chinese Face-to-Face Interaction. London: Ablex.

Pan, Yuling, and Dániel Z. Kádár. 2012. Politeness in Historical and Contemporary Chinese. London: Bloomsbury.

Sargent, Tanja Carmel. 2009. "Revolutionizing Ritual Interaction in the Classroom: Constructing the Chinese Renaissance of the Twenty-first Century." Modern China 35 (6): 632-661.

Schoenhals, Martin. 1993. The Paradox of Power in a People's Republic of China Middle School. New York: M.E. Sharpe.

Van Dijk, Teun A. 2011. Discourse Studies: A Multidisciplinary Introduction. London: Sage.

Wang, Fengyan. 2004. "Confucian Thinking in Traditional Moral Education: Key Ideas and Fundamental Features.” Journal of Moral Education 33 (4): 429-447.

Wang Xuan, Kasper Juffermans, and Caixia Du. 2015. "Harmony as Language Policy in China: An Internet Perspective." Language Policy. Retrieved from: https://www.academia. edu/14456903/Harmony_as_language_policy_in_China_An_internet_perspective

Watson, Burton (trans.) 1999. The Zen Teachings of Master Lin-Chi: A Translation of the Lin-chi Lu. New York, NY: Columbia University Press.

Watts, Richard J. 2003. Politeness. Cambridge: Cambridge University Press.

Yum, June Ock. 1988. "The Impact of Confucianism on Interpersonal Relationships and Communication Patterns in East Asia." Communication Monographs 55 (4).

Zhang, Guogang. 2007. "Relationship between Parents and Children in the Tang Dynasty." Journal of Chinese Literature and History 3: 207-249.

Zhang, Tong, and Barry Schwartz. 1997. "Confucius and the Cultural Revolution: A Study in Collective Memory." International Journal of Politics, Culture, and Society 11 (2): 189-212.

Zhu, Yunxia. 2009. "Confucian Ethics Exhibited in the Discourse of Chinese Business and Marketing Communication." Journal of Business Ethics 88: 517-528.

\section{Author's address}

Daniel Kádár

English Language and Linguistics, Centre for Intercultural Politeness Research

University of Huddersfield

Huddersfield HD1 3DH

West Yorkshire

United Kingdom

d.z.kadar@hud.ac.uk 